\title{
ДИЗАЙН
}

UDC 7.1

G. N. Lola

\section{THE METHODOLOGICAL ASPECTS OF DESIGN CONSCIOUSNESS}

St. Petersburg State University,

7-9, Universitetskaya nab., St. Petersburg, 199034, Russian Federation

The article discusses the methodological issues of design practice with a focus on the paradoxical nature of design consciousness and the ability to retain rational control over the creative process. The author represents the methodology of semiotic discursive modelling as a way to fine-tune one's consciousness. Special attention is drawn to the peculiarities of simultaneous thinking. The methodology of semiotic discursive modelling activates simultaneous thinking, develops it and helps the designer implement the concept by developing logograms that have no preferable order of reading and present themselves as complete entities. Image seems to precede a thought and thus makes it possible. Thought and its graphic expression swap places. This is how the designer should think in order to see the image that expresses the concept: without trying to configure the image in advance, he or she should suggest graphic figures that may be compatible with the interpretation of his or her idea. The methodology of semiotic discursive modelling boosts the ability to code thoughts graphically. The author compares design production with development of logograms and demonstrates how the methodology of semiotic discursive modelling can activate and enhance simultaneous thinking. Refs 5. Figs 3.

Keywords: methodology of design, creative consciousness, simultaneous thinking, semiotic model, discursive model.

\section{МЕТОДОЛОГИЧЕСКИЕ АСПЕКТЫ ДИЗАЙНЕРСКОГО МЫШЛЕНИЯ}

\section{Г.Н. Лола}

Санкт-Петербургский государственный университет,

Российская Федерация, 199034, Санкт-Петербург, Университетская наб., 7-9

Статья посвящена методологическим вопросам дизайнерской практики и фокусирует внимание на парадоксальности дизайнерского сознания и возможности сохранения рационального контроля над креативным процессом. Автор представляет разработанную им методологию семиотического дискурсивного моделирования дизайн-продукта как инструмент настройки креативного сознания. Основное внимание уделено особенностям симультанного мышления. Методология семиотического дискурсивного моделирования активирует симультанное мышление, развивает его и помогает осознать концептуальную работу как создание логограмм, которые не предусматривают предпочтительного порядка при чтении и представляют собой целостности. Изображение, графика предвосхищают мысль, делают ее возможной. Мысль и ее письменное выражение меняются местами. Так должен мыслить дизайнер - не компоновать заранее образ дизайн-продукта, а набрасывать на бумаге графические фигуры, которые окажутся интерпретацией его замысла. Методология семиотического дискурсивного моделирования позволяет развить способность к графической кодировке мыслей. Автор рассматривает процесс разработки концепции дизайн-продукта как создание логограмм и показывает, каким

(c) Санкт-Петербургский государственный университет, 2017 
образом методология семиотического дискурсивного моделирования позволяет активировать и развивать симультанное мышление. Библиогр. 5 назв. Ил. 3.

Ключевые слова: методология дизайна, креативное сознание, симультанное мышление, семиотическая модель, дискурсивная модель.

Securing rational control over the designer's creativity is one of the main challenges in the product design. This requirement stems from a paradoxical nature of design itself. On the one hand, the product design is a message from the designer to the Other, and therefore it needs a clear concept. On the other hand, the designer must embody the concept in an image and find the means of its expression, because his or her task is to impress the Other.

The designer's thinking must be logical, and yet the application of linear logic in design is limited; this renders special significance to the non-linear logic of practice, which is to a certain degree independent from the desires and tasks of the acting subject. This type of logic is paradoxical; it lacks self-control and doesn't tend to return to its basics [1]. Applied in solving constantly changing ad hoc tasks, the logic of practice has a mosaic and irregular nature: it's not so much about making conclusions but rather about suggesting hypotheses, 'guessing' the solutions.

Pre-set messages, deterministic algorithms, and standard schemes constitute only a part of design practice; quick response to changing conditions, constant adjustment of plans, conclusions, and routine are much more important. Thus, design is not a mere adhering to the concept but rather its realization according to its own dynamics. The use of non-linear logic makes the designer's consciousness sensitive, flexible, and fluid, but it doesn't solve the problem of control over creativity that is unrestrained by definition. However, the very task of gaining control over creative consciousness may be suspended with the question: is it possible to follow the creative process intellectually and contemplate it?

This is a justified question, because design production cannot be reduced to following a predetermined plan and concept; rather, it's a relatively unrestrained improvisation inspired by the original concept. Thus, the concept is a variable, not a constant: it sets the general direction, but is susceptible to modulations and requires adjustment. Treating concept in this way, designer can create an original product that even he or she may found surprising and that may receive an intellectual and emotional response from the Other.

What a contemplative attitude to thinking is can be seen in the analysis of simultaneous thinking as it appears in Ted Chiang's «Story of Your Life» [2]. The author describes semagrams, the logographic writing system of aliens called heptapods. Logograms are not letters or words but visible graphic elements that represent an idea. Logograms can't be split into sentences or recombined into new ones, they are continuous. Heptapods didn't arrange logograms in rows, spirals, or any other linear order; they glued them together into a complex conglomerate. There was no preferable way of reading logograms: one could start anywhere and move freely along the whole graphic ensemble. The protagonist of the story mastered the heptapod writing and was able to produce a graphic combination that proved to be an interpretation of what she was going to say.

This is a very important quality of the simultaneous thinking: image seems to precede a thought and thus makes it possible. The thought and its graphic expression swap places. This is how the designer should think in order to see the image that expresses the concept: 
without trying to configure the image in advance, he or she should suggest graphic figures that may be compatible with the interpretation of his or her idea. The image of the product design should be sketched as a logogram. In that case, the product design will be more interesting than the initial idea.

Slowing down is a sign of simultaneous thinking: designer looks closer and in a more sensitive way into his or her consciousness. The opposite of simultaneous thinking is quick combinatory thinking. This type of thinking is similar to piling up construction blocks. It is very effective for operating in a standard situation, but proves completely helpless in grasping the situation in general. Lester from the first season of "Fargo" was a quick thinker who could see the details, but not the bigger picture. He managed to solve the riddle about the goat, cabbage, fox, and hare, but didn't understand Molly's parable about the lost and thrown away gloves.

Simultaneous thinking, with a graphic code preceding a thought, should become an intellectual habit, not just a curiosity. My method of semiotic discursive modelling [3] helps not only identify the examples of simultaneous thinking, but also develop it.

Let's review the basic procedures of the methodology of semiotic discursive modelling.

\section{Concept}

Defining the concept is the first 'assemblage point' of the semiotic discursive model of product design. Concept is a found/created ingot of a semantic energy that appears through intuitive and rational apprehension of the sense of the would-be work in certain mental environment. A found concept is expressed in a concise and expressive formula.

The first procedure of defining the concept is formatting of the informational situation using the data given by the customer. The second procedure is finding the concept in the given context created by the specification of the 'portrait' of the Other and the competences of the subsequent product design. While the first procedure follows linear logic because it requires system analysis of the information, the second procedure would be impossible without using simultaneous thinking. Concept isn't a logical conclusion, it is to be found immanently in the same way as a philosophical concept [4]. This means that designer, having absorbed all the information, should perceive it as a whole and reveal a semantic field, transcribing the ultimate goal in his or her own way.

The construction of the semiotic discursive model starts with a concept that, like a genetic code, defines the configuration of the 'body' of the model. Concept is the start and the end, for it preserves the essence of the assignment and serves as a reference point for the customer's original task. Though it is the customer who defines the concept parameters, it is the designer who articulates them, because the elaboration of the concept can't be reduced to editing of the customer's requests; it is a complicated analytic procedure. Concept understood as an outline, a configuration of the event, is one of the most complex notions in design. Elaboration of the concept is the first and indispensable step to the construction of the semiotic discursive model. Concept is the center of its semiotic energy that powers the whole process of creation of product design.

A correctly developed concept releases creative energy, setting in on a proper course, taking control of creative solutions, disciplining and keeping it from superfluous motions; in the end, it creates the matrix of impression. However, concept should not be seen as the 
philosopher's stone that produces creative miracles. In fact, it is the opposite: after a concept is successfully appropriated, it should reach a subconscious level, and from there test creative solutions by means of intuition. So, concept should be found, admired, thought through... and forgotten. Only a general mood should linger on: designer has to be inside the concept and start semiotic modelling with a light and empty head. This is a self-deception, but designer has to indulge in it lest he or she scares off the image, for it comes to those who are ready to receive it gratefully as a gift (image is indeed a gift).

The rule of concept: 'It changes'. Concept defines the whole process of creating product design, and must therefore be profoundly consistent. However, its permanence is relative as that of a living person. Concept needs to go down a hard path of self-knowledge, becoming mature and thus changing in the end. This ability to change is essential to it. Concept sets the limits of the possible without constraining the possibilities. If we perceive concept not as a given, but as a process, if we don't develop it but construct it, it will become a Pole Star, and not an obsession.

\section{Semiotic Model}

Semiotic modelling enables viewing the image: the concept code activates semiotic resources, and then the semiotic field transforms, by means of connotations, into a semiotic situation, a sort of energetic substance that makes image visible. As the image becomes clearer, its metaphor and motif become definite, fully arranging the semiotic situation and allowing for its description in a basic narrative.

If concept in the semiotic discursive model can be compared to the genetic code, then image is the body. The construction of the semiotic discursive model is simultaneous with the construction of the image; each stage of this construction is an approach to the image and its various implementations. First, the outlines of the image should be defined by the semiotic model that prepares its vision; then the achieved result should be specified by the discursive model. The semiotic model shall have the contexts of perception in the discursive mode.

Translation of the image-semiotic model into image-discursive model is done through contextualization practices that invest the image with autonomy and its own development logic. Semiotic modelling is instrumental in preparing the situation in which an image may appear rather than in 'creating' that image. This means that a semiotic model must be found as a whole rather than composed of semiotic resources.

Every procedure of semiotic modelling can be considered in terms of creative condition and creative action. Creative condition works as a 'background' against which an image appears while creative action refers to the thought-through acts of processing this image. Semiotic modelling is well represented in the following scheme: the concept-code starts concentrating semiotic resources and creates a semiotic situation that suggests a metaphor; getting a feel for the metaphor activates an image and clarifies it; as the image gets clearer, one finds a motif that centers and orders a semiotic situation, renders further precision to the metaphor, and makes the image so distinct that it can now be described in the basic narrative.

All these actions are accompanied by modelling of creative conditions or, more precisely, by their modulation from absorption to detachment. The procedures of semiotic modelling follow each other and thus require certain succession of mental acts; however, the pivotal points a designer finds in the process of semiotic modelling - namely, a met- 
aphor, a motif, and a basic narrative - should not result from the logically accurate reasoning. There is no cause-and-effect relationship between these narrative actions. There are gaps and lacunae between them.

The rule of semiotic model: 'It manifests itself'. Don't create a semiotic model, let it create itself. Semiotic model is dynamic and flexible, it is loosely connected with the image; it is to bring it closer while it is still concealed. Thus, semiotic modelling of the image is modelling round and round the image. It is important not to hurry and try to imagine or even define the image. Image has to manifest itself.

The basic narrative fixates the semiotic model and articulates an image; implicitly, it contains the instruments to be used to represent an image in an object. To bring an image into a basic narrative is to render a new quality to it. This process may be explained in terms of 'crystalline grid' and 'plasma'. The basic narrative puts the image into the 'crystalline grid' by endowing it with the stable ordered periodic structure. At this moment the image coincides with the model.

Later, basic narrative is to change its state into plasma; it ceases being a structure and turns into a clot of meaning. This means that a semiotic model must have, while preserving its distinctness, a span of freedom and a program of development. This program is unfolded by the practice of contextualization that turns a semiotic model into a discursive semiotic model. However detailed a semiotic model might be, it will further develop and alter in communicative space. The practices of contextualization do help predict the ways of this development. By turning a semiotic model into a discursive model, they create a construction of meaning open to re-signification and ready to enter a communication process.

Semiotic modelling to a significant degree activates simultaneous thinking, because designer can't create a semiotic situation for producing the image of the future product design without perceiving the whole mental landscape.

\section{Discursive Model}

Discursive modelling is a combination of practices contextualizing the semiotic core of an image. The first procedure is 'discourse mapping': moving to the border of the image and introducing guiding codes, thus enriching the semantic potential of the semiotic model. The second procedure is re-contextualization that puts the codes into the system and fixes them as parts of the metanarrative.

After designer has expressed the concept in a visible and sensible image, in a semiotic model, he or she needs to produce the image of the Other using this model. This task is solved by discursive modelling, which starts simultaneously with the actual design development. Unlike semiotic modelling, discursive modelling is done in the course of work, because the solutions depend of the very tools and fluid context (emotional, intellectual, social, political) of the work.

Methodologically, creation of a discursive model rests on the neopragmatic social semiotics that considers contextualization a semiotic practice of endowing with meaning. Social semiotics distinguishes three types of contexts, namely the syntagmatic (it considers actions, events, and phenomena in their succession), the paradigmatic (it juxtaposes, compares, and pulls together actions, events and phenomena) and the indexical (it brings together events that are interconnected within a given situation rather than presents various interpretations of a single event) [5]. 
To create a discursive semiotic model of a product design, the methodology of semiotic discursive modelling uses all the three practices of contextualization. However, indexical contextualization enjoys the priority since it opens up the horizons of continuous signification and resignification thus involving a user into stable and personalized communication. To actualize the indexical context is to increase an image's interpretative resource by suggesting an activity and free choice of meaning to the participants of communication. As a result, we receive a possibility of 'self-adjustment' with regard to what is being interpreted. In this sense, indexical contextualization turns a user into a participant of the design process.

All of these contextualization practices change the distance between the possible understanding by the Other and the semantic core created by the designer. Thus, the semiotic model fixated in the basic narrative becomes a basis for contextualization practices. The transformation of a semiotic model into a discursive one is accompanied by the transversion of a basic narrative into a metanarrative - a verbal construction capable of simultaneously fixating the products of contextualization and creating the projections of future contexts.

Construction of the image is a single action that has two dimensions and is done by simultaneous application of two technologies: the first one provides the vision of the image in its complete integrity while the second destroys the integrity of the image and unwraps it into a discursive practice, or the construction of meanings. Discursive modelling pursues an important task of giving out the 'keys' to the Other. In other words, it produces a communication that makes it possible for the Other who has found a code to recognize it as her/his own. This recognition of 'mine' in someone else's is the ultimate aim of discursive modelling.

The rule of discursive model: 'It disappears. The discursive model doesn't provide the Other with ready-made meanings, but lets the Other extract them and even imbue the perceived image with the Other's own meanings. The discursive model anticipates impression, giving the Other an opportunity to create meanings.

Discursive modelling fully activates simultaneous thinking. 'Discourse mapping' can't be done with linear thinking, because designer needs to the see the whole mental space at once and move inside it freely, dropping codes and then reassembling them in 'constellations.' This discourse map will help the Other navigate in the semantic space of the product design. Simultaneous thinking allows for recognition and solution of a paradoxical task: to see the discourse map, or the context of perception of the image by the Other, as a whole. Only in this case, the Other will perceive the suggested set of interpretations as a natural (not imposed) semantic space.

The rule of semiotic discursive modelling of the product design is: everything (concept, image, product) emerges regardless of the resources. The procedures and acts of semiotic discursive modelling require a sequence of mental acts, and yet the key points the designer holds on to (concept - metaphor - motif - basic narrative - guiding codes metanarrative) are not held together by a linear logic. There are lacunas and gaps between these narrative acts.

Design begins with a precisely defined idea that is to be changed in the process of its implementation. The concept still defines the goal of the design practice, arranges and disciplines it, yet leaving from empty space for an experiment, improvisation, and prompt 


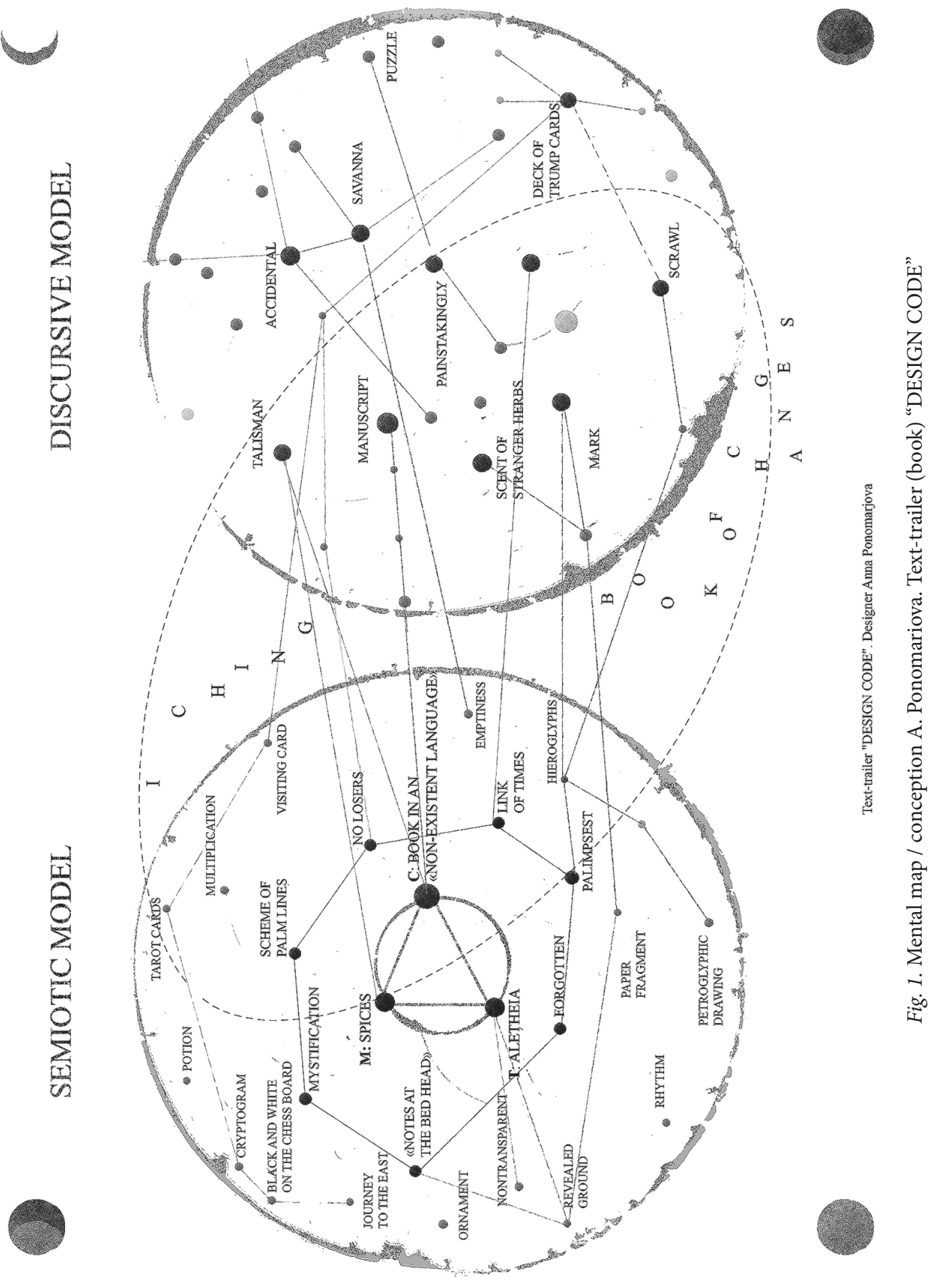




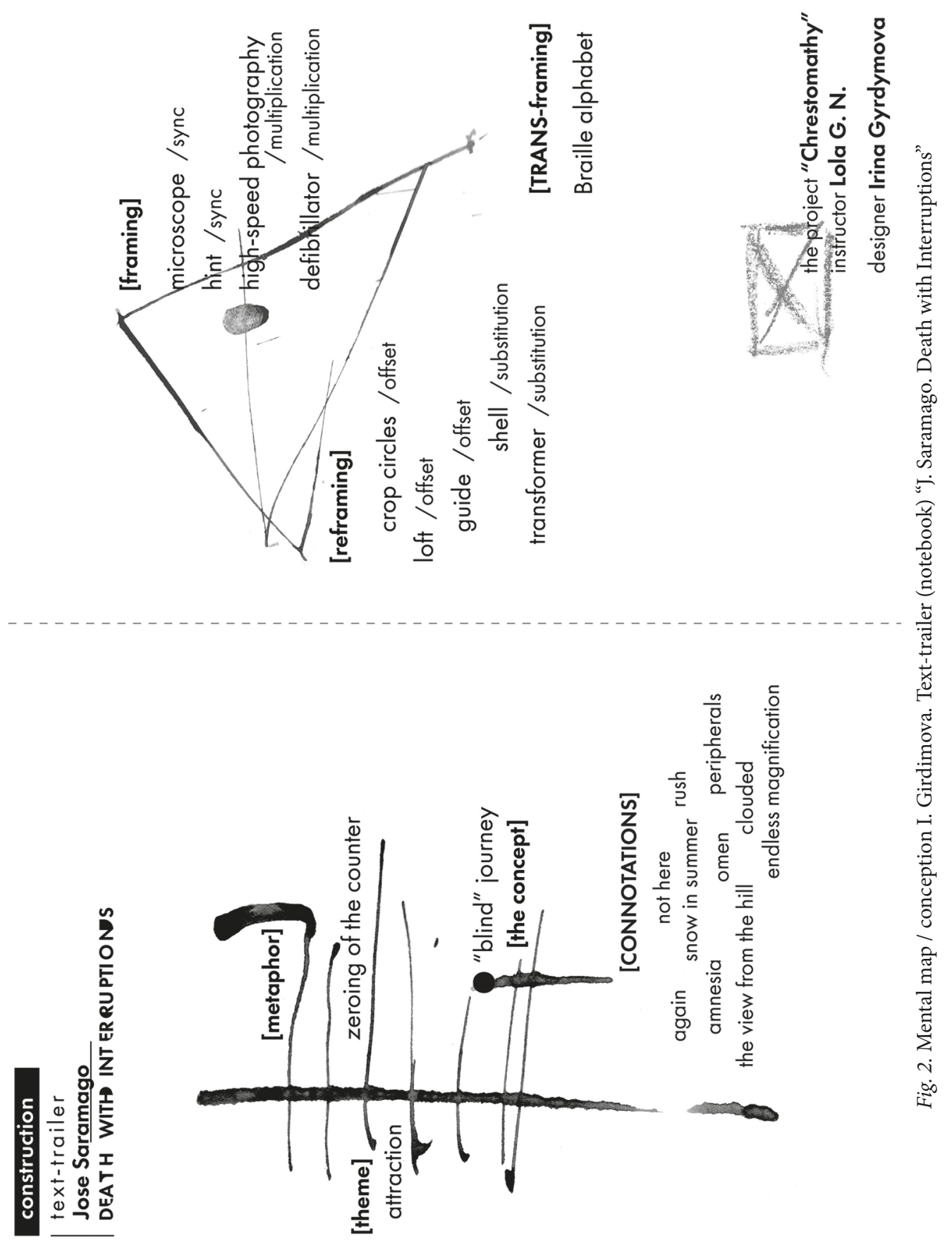




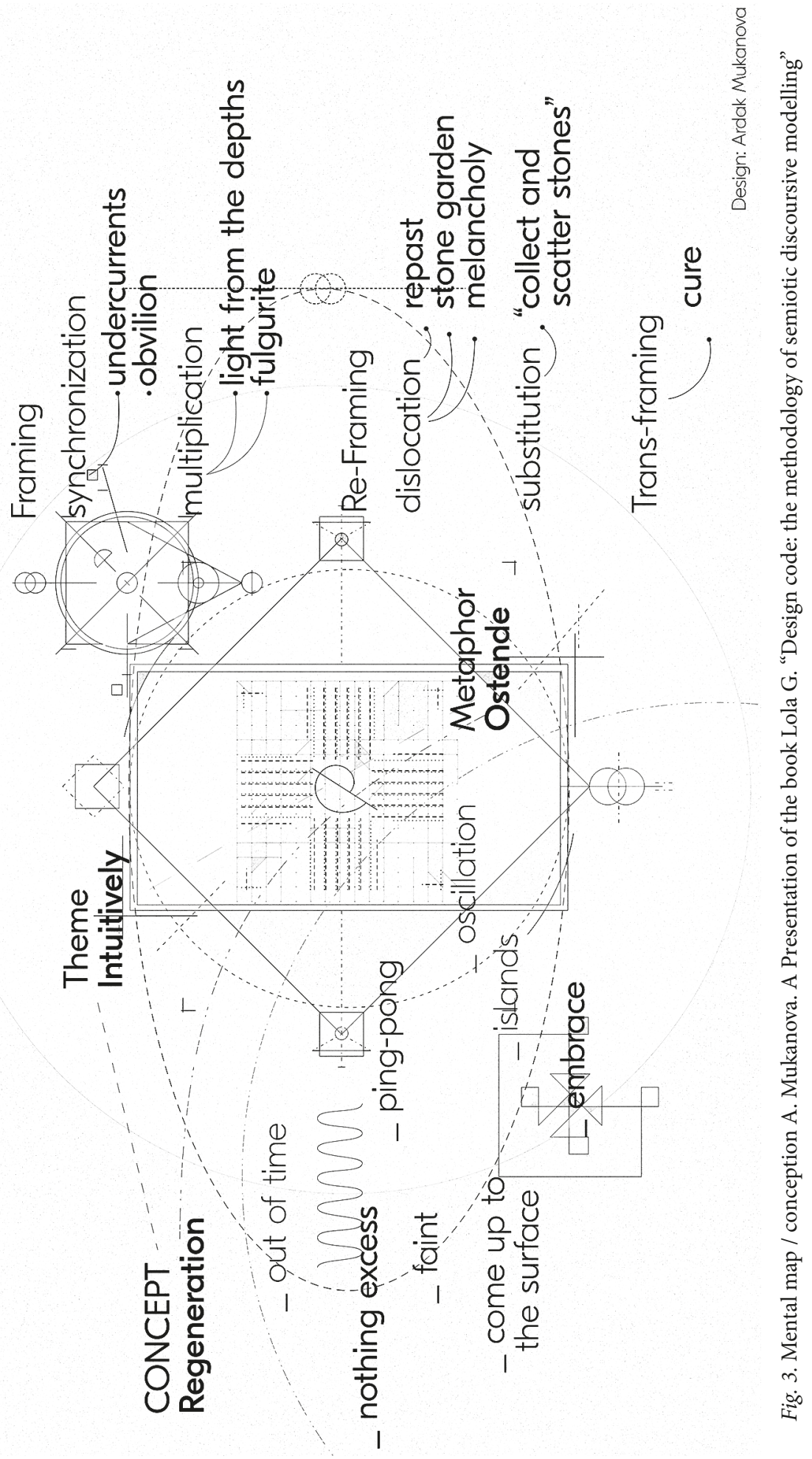


reactions to the changing situation. This results in a product that is equally predictable and unpredicted. This difficult-to-predict quality of the result is a necessity. The methodology of semiotic discursive modelling of product design activates the non-linear logic of practices, because the pulsating nature of designer's creativity requires an advanced spatial imagination and the ability to switch points of observation of a semantic landscape, leaping over its semantic gaps. In that sense, this methodology is not a guidebook in effective creative design, but a way to fine-tune one's consciousness, putting it into the state when ideas come, images emerge, and proper tools are found.

The methodology of semiotic discursive modelling activates simultaneous thinking, develops it and helps designer implement the concept by developing logograms that have no preferable order of reading and, as entities, can't be modified without irreversible damage to their meaning. The methodology of semiotic discursive modelling boosts the ability to code thoughts graphically. Therefore, designers who have mastered this methodology prefer to describe the design concepts not with briefs, but with mental maps. This format helps develop a mental landscape that makes it possible to follow the creative process rationally.

\section{References}

1. Bourdieu P. The Logic of Practice. Transl. R. Nice. Cambridge, Polity Press, 1990. 340 p.

2. Chan T. Istoria tvoei zhizni [Chiang T. Story of Your Life]. Moscow, AST, 2016, pp. 216-279. (In Russian)

3. Lola G. Dizain-kod: metodologia semioticheskogo diskursivnogo modelirovaniia [Lola G. Design code: the methodology of semiotic discursive modelling]. St. Petersburg, IPK Beresta Publ., 2016. 264 p. (In Russian)

4. Deleuze J., Guattari F. Chto takoe filosofia? [What is Philosophy?]. St. Petersburg, Aleteya Publ., 1998. 288 p. (In Russian)

5. Lemke, J.L. Discourse, Dynamics, and Social Change. Cultural Dynamics. (Ed. Leiden: Brill.), vol. 6 (1), 1993, pp. 243-275.

For citation: Lola G.N. The methodological aspects of design consciousness. Vestnik SPbSU. Arts, 2017, vol. 7, issue 4, pp. 472-481. https://doi.org/10.21638/11701/spbu15.2017.407

\section{Authors information}

Lola Galina N. - Doctor of Philosophy; galina_lola@mail.ru

Лола Галина Николаевна - доктор философских наук; galina_lola@mail.ru 